\title{
Pig-farming systems and porcine cysticercosis in the north of Cameroon
}

\author{
E. Assana ${ }^{1}$, F. Amadou ${ }^{2}$, E. Thys ${ }^{1}$, M.W. Lightowlers ${ }^{3}$, \\ A.P. Zoli ${ }^{2}$, P. Dorny ${ }^{1}$ and S. Geerts ${ }^{1 *}$ \\ ${ }^{1}$ Department of Animal Health, Institute of Tropical Medicine, \\ Nationalestraat 155, B-2000 Antwerpen, Belgium: ${ }^{2}$ Faculty of Agronomy \\ and Agricultural Sciences, University of Dschang, P.O. Box 222, Dschang, \\ Cameroon: ${ }^{3}$ Veterinary Clinical Centre, University of Melbourne, \\ 250 Princes Hwy, Werribee, Victoria 3030, Australia
}

(Accepted 18 February 2010; First Published Online 25 March 2010)

\begin{abstract}
A survey was conducted in 150 households owning 1756 pigs in the rural areas of Mayo-Danay division in the north of Cameroon. A questionnaire survey was carried out to collect information on the pig-farming system and to identify potential risk factors for Taenia solium cysticercosis infection in pigs. Blood samples were collected from 398 pigs with the aim of estimating the seroprevalence of T. solium cysticercosis. The results showed that $90.7 \%$ of the pigs are free roaming during the dry season and that $42.7 \%$ of households keeping pigs in the rural areas have no latrine facility. Seventy-six per cent of the interviewed pig owners confirmed that members of the household used openfield defecation. Enzyme-linked immunosorbent assay (ELISA) for antigen and antibody detection showed an apparent prevalence of cysticercosis of $24.6 \%$ and $32.2 \%$, respectively. A Bayesian approach, using the conditional dependence between the two diagnostic tests, indicated that the true seroprevalence of cysticercosis in Mayo-Danay was $26.6 \%$. Binary logistic regression analysis indicated that a lack of knowledge of the taeniasis-cysticercosis complex and the absence of a pig pen in the household were associated with pig cysticercosis.
\end{abstract}

\section{Introduction}

Taenia solium cysticercosis is a severe zoonotic disease, which causes serious public health problems and provokes economic losses in the areas where it is endemic, particularly in developing countries (Zoli et al., 2003; Carabin et al., 2006; Praet et al., 2009). The important findings concerning the control of T. solium cysticercosis during the past two decades were reviewed by Pawlowski et al. (2005). One of the most important conclusions is that tapeworm carriers and human and porcine cysticercosis cases cluster in endemic foci. The risk factors for human cysticercosis are frequent consumption of pork, poor hygiene and having a history of taeniasis (Flisser \& Gyorkos, 2007). Although the

*Fax: 00-32-3-2476268

E-mail: sgeerts@itg.be presence of free-roaming pigs in rural areas of developing countries was identified as an important risk factor for swine cysticercosis (Sikasunge et al., 2007), this is not the only way for pigs to get access to human faeces. Direct defecation of pig keepers in pig pens has been reported in the west of Cameroon (Zoli et al., 1987; Shey-Njila et al., 2003). The Mayo-Danay division is the most important region for pig breeding in northern Cameroon. In this part of the country, pigs are kept by non-Muslim people who interact with an important Muslim community. Pig husbandry is traditional and involves mainly local breeds which receive some domestic waste and little feed supplement (Njoya et al., 1997; Koussou, 1999). Limited data from earlier studies in northern Cameroon suggested hyperendemicity of human and porcine cysticercosis (Awa et al., 1999, Assana et al., 2001), but details are not known concerning the factors that predispose to the infection of pigs. The main objective of this study was to 
update data on swine cysticercosis and identify risk factors for this zoonosis in the Mayo-Danay division.

\section{Materials and methods}

\section{Study area}

The Mayo-Danay division is located in the far northern province of Cameroon (fig. 1). The annual average rainfall varies from 600 to $800 \mathrm{~mm}$ and the wet season lasts 5 months - from May to October - while little or no rain falls during the rest of the year. Temperatures vary from maximum of around $45^{\circ} \mathrm{C}$ to a minimum of $20^{\circ} \mathrm{C}$. The total population is about 600,000 inhabitants. There are four predominant ethnic groups: the Massa, the Toupouri, the Mousgoum and the Moussey, who are largely animistic or Christian and primarily involved in crop and livestock production. Livestock activities include keeping of cattle, sheep, goats, poultry and pigs. Pig raising is possible because most of the population is non-Muslim.

\section{Survey design and data collection}

A survey was conducted in Mayo-Danay division between June 2007 and April 2008. A one-visit, multipleobjects survey was carried out to collect information on the pig-farming system. One hundred and fifty households, keeping 1756 pigs, were randomly sampled out of the registries kept by the authorities in the major area of pig farming. These rural areas were identified following the preliminary study carried out by Assana et al. (2001). Three hundred and ninety-eight (398) blood samples from pigs were collected in these surveyed households. A preliminary study had shown that the seroprevalence of pig
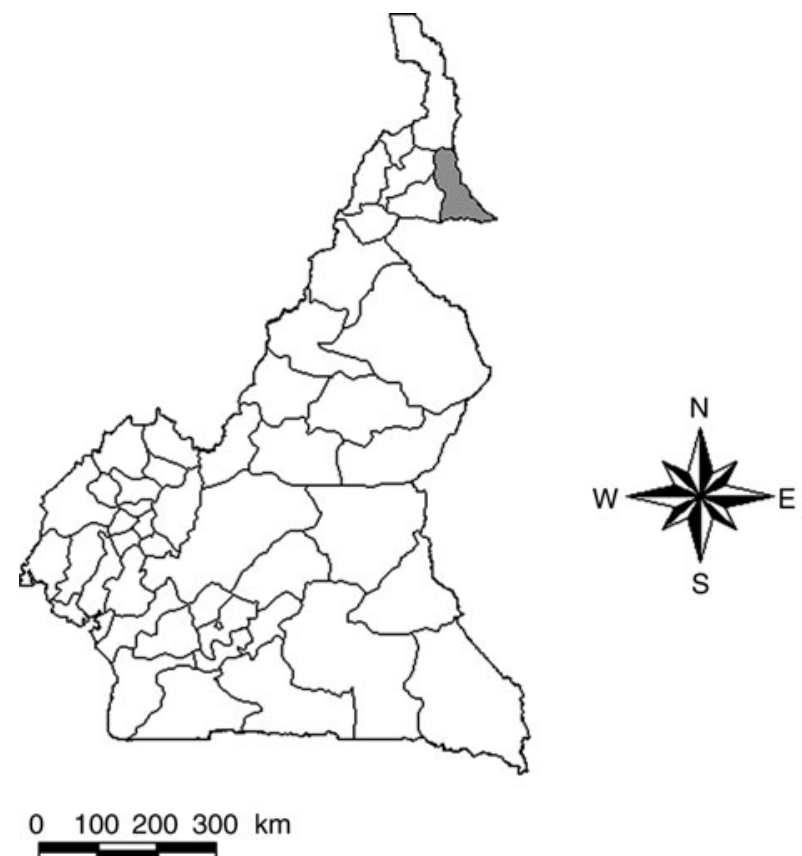

Fig. 1. Map showing the study area (Mayo-Danay division, grey shading) in the north of Cameroon (all other Cameroon districts shown as white areas). cysticercosis in Mayo-Danay was 39.8\% (Assana et al., 2001). Assuming that a maximum sample size of 384 is required at the prevalence level of 50\% (Sikasunge et al., 2008), at least 368 pigs were needed in this study according to the formula $n=Z^{2} P Q / L^{2}$, where $n$ is the required sample, $Z$ is the $Z$ score for confidence, $P$ is the known prevalence, $Q=(1-P)$ and $L$ is the error estimation at $95 \%$ confidence (Martin et al., 1987). Therefore, a sample size of 398 pigs is easily sufficient to estimate the prevalence of pig cysticercosis in Mayo-Danay division.

\section{Serology}

\section{Serum samples}

Serum samples collected from pigs during the survey were stored at $-20^{\circ} \mathrm{C}$ until tested. Two positive serum samples from naturally infected pigs and eight negative serum samples from pigs from a local commercial pig farm without any history of cysticercosis were included as reference control sera in the enzyme-linked immunosorbent assay (ELISA).

\section{Enzyme-linked immunosorbent assay for the detection of circulating $\mathrm{T}$. solium antigens (Ag-ELISA)}

The Ag-ELISA was performed as described by Brandt et al. (1992) and modified by Dorny et al. (2004). Briefly, the sera were pre-treated using trichloroacetic acid (TCA) and used in ELISA at a final dilution of $1 / 4$. The monoclonal B158 was diluted at $5 \mu \mathrm{g} / \mathrm{ml}$ in carbonate buffer $(0.06 \mathrm{M}, \mathrm{pH} 9.6)$ for coating the ELISA plate and the biotinylated monoclonal antibody (MoAb) B60 (1.25 $\mu \mathrm{g} /$ $\mathrm{ml}$ in phosphate-buffered saline containing $0.05 \%$ Tween 20 (PBS-T20)/1\% newborn calf serum (NBCS)) was included as detector antibody. The incubation was carried out at $37^{\circ} \mathrm{C}$ on a shaker for $30 \mathrm{~min}$, for the coating of the first $\mathrm{MoAb}$, and for $15 \mathrm{~min}$ for all subsequent steps. The chromogen/substrate solution, consisting of orthophenylene diamine (Dako, Glostrup, Denmark) and $\mathrm{H}_{2} \mathrm{O}_{2}$ was added and incubated without shaking between 30 and $33^{\circ} \mathrm{C}$ for $15 \mathrm{~min}$. To arrest the reaction, $50 \mu \mathrm{l}$ of $4 \mathrm{~N}$ $\mathrm{H}_{2} \mathrm{SO}_{4}$ was added to each well. The plates were read using an ELISA reader (Multiskan RC, MTX Lab Systems, Vienna, Virginia, USA) at $492 \mathrm{~nm}$.

Enzyme-linked immunosorbent assay for the detection of antibodies against $\mathrm{T}$. solium cysticerci (Ab-ELISA)

The ELISA for the detection of antibodies against T. solium cysticerci (Ab-ELISA) was based on a $14 \mathrm{kDa}$ antigen (F3 antigen) purified from T. solium cyst fluid by a two-step chromatography, as described by Assana et al. (2007). The antigen (F3) was diluted at $1 \mu \mathrm{g} / \mathrm{ml}$ in a carbonate buffer $(0.06 \mathrm{M}, \mathrm{pH} 9.6)$ for coating $\left(1 \mathrm{~h}\right.$ at $37^{\circ} \mathrm{C}$ and overnight at $4^{\circ} \mathrm{C}$ ). PBS-T20 was used for washing between steps. Serum samples and conjugate were blocked and incubated on a shaking plate for $1 \mathrm{~h}$ at $37^{\circ} \mathrm{C}$. PBS-T20/NBCS was used for blocking. Serum samples were diluted at $1 / 300$. A rabbit anti-pig IgG peroxidase conjugate (Sigma, St. Louis, Missouri, USA) was used at a dilution of $1 / 30,000$. The wells were washed three times, and the final steps were executed as described for the Ag-ELISA. 
For both Ag- and Ab-ELISA, the optical density (OD) of each serum sample was compared with a series of reference negative serum samples $(n=8)$ at a probability level of $P=0.001$ to determine the cut-off, using a modified Student's $t$-test (Sokal \& Rohlf, 1981).

\section{Statistical analysis}

A Bayesian analysis was used to estimate the true prevalence of cysticercosis in the Mayo-Danay division and the sensitivity (Se) and specificity (Sp) of both Ag-ELISA and Ab-ELISA tests using a multinomial model as described by Krecek et al. (2008). Briefly the results from Ag-ELISA and Ab-ELISA were combined together in a Bayesian model and run in Wingbugs 1.4 (Spiegelhalter et al., 2003). The prior information was obtained from previous studies on diagnosis of cysticercosis (Pouedetet al., 2002; Dorny et al., 2004; Assana et al., 2007). The sensitivity and specificity of the Ag-ELISA were constrained to intervals $(0.8,1)$ and $(0.9,1)$, respectively, whereas the sensitivity and specificity of the Ab-ELISA were constrained to intervals $(0.4,1)$ and $(0.5,1)$. The validation of the model was based on the number of parameters $(P \mathrm{D})$, the Deviance Information Criterion (DIC) values from posterior mean of the multinomial probabilities (DIC_Pr) and from posterior mean of the parameter of the model using parent nodes (DIC_P) and on the Bayesian- $p$ values (Bayesp) as described by Berkvens et al. (2006). To identify risk factors for pig cysticercosis, logistic regression was performed as described by Prasad et al. (2007). A pig that had a positive result in the Ag- or Ab-ELISA was considered as an infected pig in the analysis of risk factors.

\section{Results}

\section{Pig-farming systems and sanitary facilities}

Most of the pig farmers (90.7\%) in the Mayo-Danay division kept pigs in a free-roaming system during the dry season. In the rainy season, pigs were confined in a small pig pen. From the 150 farmers interviewed, only $4.9 \%$ practised permanent indoor pig raising, whereas $13.7 \%$ allowed the pigs to roam freely during the rainy season (since there is sometimes overlapping of various systems, the total figure exceeds $100 \%$ ). The survey showed that $16 \%$ of the households did not have a pig pen. Furthermore, it revealed that $42.7 \%$ of the households keeping pigs had no latrine facilities and that $76.0 \%$ of the pig farmers declared that the members of their family used open-field defecation.

\section{Serology}

The overall seroprevalence of pig cysticercosis was 24.6 and $32.2 \%$ for Ag-ELISA and Ab-ELISA, respectively.
Of the total of 150 households surveyed, $56.0 \%$ and $57.3 \%$ of them had at least one pig positive for porcine cysticercosis in Ag-ELISA and Ab-ELISA, respectively.

\section{Bayesian analysis}

There was a good correlation between the results obtained by Ag-ELISA and Ab-ELISA. Two hundred and twenty-eight out of 398 sera were negative in both Ag- and Ab-ELISA, whereas 56 out of 398 sera were positive in both tests. The estimated true prevalence using Bayesian analysis was $26.6 \%$ (95\% CI: $15.6-31.0 \%)$. Forty-two sera were only positive in the Ag-ELISA and 72 only in the Ab-ELISA. The sensitivity and specificity of the Ag-ELISA and Ab-ELISA used for the diagnosis of pig cysticercosis in the Mayo-Danay division are presented in table 1 . The validation criteria of the Bayesian model are shown in table 2.

\section{Risk factor analysis}

The factors that were considered as significant risks for pig cysticercosis are presented in table 3 . The seroprevalence of cysticercosis in pigs was found to be associated with the pig owner's level of knowledge about the taeniasiscysticercosis complex (odds ratio $(\mathrm{OR})=0.360, P<0.05$ ) and pig pen availability $(\mathrm{OR}=0.45, P<0.05)$.

\section{Discussion}

\section{Risk factors for porcine cysticercosis}

In 1980, the pig population in Cameroon was estimated at more than 1,000,000 and $60 \%$ of the pigs were located in the western part of the country. After an outbreak of African swine fiver (ASF) in 1982 (Nana-Nukechap \& Gibbs, 1985), the pig population decreased in this part of the country. Since 1990, the north of Cameroon, free from ASF, emerged as the main provider of pork for the city of Yaoundé (Ndebi \& Ongla, 2006). Pigs are kept in a traditional low-input breeding system (Njoya et al., 1997), which favours infection with T. solium (Awa et al., 1999). The results of this survey showed that $42.7 \%$ of households keeping pigs in the rural areas have no latrine facility and $76 \%$ of pig farmers use open-field defecation around the households. Even when a latrine was available this did not imply that it was used by the members of the household. In fact, these latrines were built to avoid problems with the sanitary authority, which controls the availability of latrines in the villages on a regular basis.

The coexistence of poor sanitary conditions and free roaming of domestic pigs (absence of pig pens; $\mathrm{OR}=0.45 ; P<0.05)$ certainly plays an important role in

Table 1. The true prevalence of porcine cysticercosis in Mayo-Danay and the sensitivity (Se) and specificity (Sp) of Ag-ELISA and Ab-ELISA estimated by means of Bayesian analysis (with $95 \%$ confidence intervals).

\begin{tabular}{lcccccc}
\hline & & \multicolumn{2}{c}{ Ag-ELISA } & & \multicolumn{2}{c}{ Ab-ELISA } \\
\cline { 3 - 4 } Combined test & True prevalence & Se & Sp & & Se & Sp \\
\hline Ag-ELISA/Ab-ELISA & $0.266(0.156-0.310)$ & $0.895(0.804-0.994)$ & $0.947(0.902-0.997)$ & & $0.585(0.425-0.787)$ & $0.754(0.689-0.818)$ \\
\hline
\end{tabular}


Table 2. Model validation based on Bayesp, DIC and PD used to estimate the prevalence of cysticercosis in Mayo-Danay division and the sensitivity and specificity of Ag-ELISA and Ab-ELISA.

\begin{tabular}{llllll}
\hline Combined test & Bayesp & PD_Pr & PD_p & DIC_Pr & DIC_P \\
\hline Ag-ELISA/Ab-ELISA & 0.492 & 2.983 & 2.941 & 22.994 & 22.894 \\
\hline
\end{tabular}

Bayesp, Bayesian- $p$ values; DIC, Deviance Information Criterion; DIC_Pr, DIC values from posterior mean of the multinomial probabilities; DIC_P, DIC values from posterior mean of the parameter of the model using parent nodes.

the circulation of T. solium infection in the region. Free roaming of pigs is known to be an important risk factor for infection of pigs with T. solium (Sikasunge et al., 2007). This is not the case in the west and north-west of Cameroon where direct defecation by people in pig pens is an important factor associated with transmission of cysticercosis (Zoli et al., 1987; Shey-Njila et al., 2003). In addition, pigs are privately slaughtered without meat inspection. When answering the questionnaire, pig keepers knew and recognized pig cysticercosis through tongue examination or in pig meat, but did not know the relationship between taeniasis in humans and the presence of cysticerci in pigs. This lack of knowledge about the transmission of T. solium $(\mathrm{OR}=0.360 ; P<0.05)$ may contribute to the maintenance of a high prevalence of pig cysticercosis in the region.

\section{Prevalence of porcine cysticercosis}

In an earlier epidemiological survey conducted in the Mayo-Danay division in 1999, 38.9\% of the pigs were found to be seropositive using an ELISA for antigen detection (Assana et al., 2001). The results of the ELISAs in the present study ( $24.6 \%$ seropositive by Ag-ELISA and $32.2 \%$ by Ab-ELISA) are somewhat lower but confirm that pigs are still highly exposed to T. solium cysticercosis. However, neither of the tests used for the diagnosis of cysticercosis is perfect (Dorny et al., 2004, Krecek et al., 2008). The Ab-ELISA, using a $14 \mathrm{kDa}$ purified antigen (F3), is more specific but less sensitive than the Ag-ELISA (Assana et al., 2007). It measures the exposure of the pigs to $T$. solium, but this does not imply that cysticerci are present. The Ag-ELISA, on the other hand, detects the presence of living cysts, but cross-reacts with Taenia hydatigena. The advantage of using both the Ab-ELISA and the Ag-ELISA and analysing the results in a Bayesian model is that the F3 antigen used in the former test does not react with serum samples from pigs infected with T. hydatigena (Assana et al., 2007). However, the occurrence of $T$. hydatigena is not well known in northern Cameroon and should be studied further. The seroprevalence of cysticercosis using Ab-ELISA was higher than when using Ag-ELISA. This seems to indicate that a proportion of the pigs harbour only dead cysts or have specific transient antibodies against cysticercosis (Garcia et al., 2001). In our study, $37 \%(42 / 114)$ of the serum samples positive in Ag-ELISA tested negative in Ab-ELISA. This discrepancy might be due to the lower sensitivity of the Ab-ELISA or to false-positive results in Ag-ELISA due to cross-reaction with T. hydatigena. Similar high proportions

Table 3. Univariate analysis of risk factors associated with seroprevalence of porcine cysticercosis in Mayo-Danay.

\begin{tabular}{|c|c|c|c|c|c|}
\hline \multirow[b]{2}{*}{ Variable } & \multirow[b]{2}{*}{ Level } & \multirow[b]{2}{*}{$\begin{array}{l}\text { Total number } \\
\text { of pigs }\end{array}$} & \multirow[b]{2}{*}{$\begin{array}{l}\text { Seropositive } \\
\text { pigs }(\%)\end{array}$} & \multicolumn{2}{|c|}{ Statistical significance } \\
\hline & & & & $P$ & Odds ratio $(95 \% \mathrm{CI})$ \\
\hline \multirow[t]{2}{*}{ Free-roaming pig system in dry season } & No & 30 & $5(16.7)$ & 0.298 & $1.691(0.629-4.544)$ \\
\hline & Yes & 368 & $93(25.3)$ & & \\
\hline \multirow[t]{2}{*}{ Free-roaming pig in rainy season } & No & 344 & $90(26.2)$ & 0.077 & $0.491(0.223-1.080)$ \\
\hline & Yes & 54 & $8(14.8)$ & & \\
\hline \multirow[t]{2}{*}{ Size of the household } & $<8$ & 126 & $32(25.4)$ & 0.807 & $0.941(0.578-1.533)$ \\
\hline & $\geq 8$ & 272 & $66(24.3)$ & & \\
\hline \multirow[t]{2}{*}{ Duration of pig farming (years) } & $<5$ & 77 & $22(28.6)$ & 0.371 & $0.775(0.444-1.354)$ \\
\hline & $\geq 5$ & 321 & $76(23.7)$ & & \\
\hline \multirow{2}{*}{$\begin{array}{l}\text { Pig owner's level of knowledge } \\
\text { of the taeniasis-cysticercosis complex }\end{array}$} & Poor & 354 & $93(26.3)$ & 0.037 & $0.360(0.130-0.940)$ \\
\hline & Average and good & 44 & $5(11.4)$ & & \\
\hline \multirow[t]{2}{*}{ Pig pen availability } & No & 49 & $16(32.7)$ & 0.016 & $0.446(0.231-0.860)$ \\
\hline & Yes & 349 & $62(17.8)$ & & \\
\hline \multirow[t]{2}{*}{ Latrine availability } & No & 142 & $36(25.4)$ & 0.802 & $0.941(0.586-1.512)$ \\
\hline & Yes & 256 & $62(24.2)$ & & \\
\hline \multirow[t]{2}{*}{ Latrine use } & No & 297 & $74(24.9)$ & 0.816 & $0.939(0.554-1.593)$ \\
\hline & Yes & 101 & $24(23.8)$ & & \\
\hline \multirow[t]{2}{*}{ History of tapeworm infection in the household } & No & 341 & $84(24.6)$ & 0.991 & $0.996(0.519-1.911)$ \\
\hline & Yes & 57 & $14(24.6)$ & & \\
\hline \multirow[t]{2}{*}{ Preference for cooking meat } & Long cooking & 68 & $17(25.0)$ & 0.937 & $0.976(0.534-1.784)$ \\
\hline & Grilled meat & 330 & $81(24.5)$ & & \\
\hline
\end{tabular}


of positive sera in antigen detection found negative in antibody detection were obtained with Ab-ELISA using crude antigen from T. solium (Pouedet et al., 2002), crude antigen from T. crassiceps (Dorny et al., 2004) and also in a recent study using an enzyme-linked immunoelectrotransfer blot assay (EITB) based on affinity purified glycoproteins from T. solium cysticerci (Krecek et al., 2008). In the absence of data from autopsy (slicing of all muscles), which is the gold standard, it is possible to use conditional dependence between two or more imperfect tests to estimate the true prevalence of a disease and its test parameters by using a Bayesian analysis (Dendukuri \& Joseph, 2001; Berkvens et al., 2006). In this study, we used conditional dependence between Ag-ELISA and $\mathrm{Ab}$-ELISA to estimate the true prevalence of cysticercosis in the Mayo-Danay division. The Bayesian analysis indicated a true prevalence of $26.6 \%$. This result is higher than the figure of $12 \%$ found by Pouedet et al. (2002) in western Cameroon, using a similar approach. The Bayesian analysis of these data revealed the sensitivity and specificity of the Ag-ELISA to be higher than those found with the Ab-ELISA (table 1). However, the diagnostic characteristics of the Ab-ELISA using F3 antigen and the EITB, the assay most commonly used for antibody detection in the diagnosis of cysticercosis (Tsang et al., 1989), seem to be similar to those reported by Krecek et al. (2008), who used the same Bayesian approach.

In conclusion, this study clearly shows that porcine cysticercosis is hyperendemic in Mayo-Danay and that the pig-farming system contributes to maintaining this high level of infection. This situation calls for preventive measures to control pig cysticercosis in the region.

\section{Acknowledgements}

This study was supported by the Wellcome Trust (United Kingdom) through project 075818; from the National Health and Medical Research Council (Australia) grant 350279; and, in part, by pig project funds from the Diocese of Yagoua (Cameroon) and the Ministry of Livestock, Fisheries and Animal industries (Cameroon). We acknowledge the help of R. De Deken in preparing the figure.

\section{References}

Assana, E., Zoli, P.A., Sadou, H.A., Nguekam, Voundou, L., Pouedet, M.S.R., Dorny, P., Brandt, J. \& Geerts, S. (2001) Prevalence de la cysticercose porcine dans le Mayo-Danay (Nord-Cameroun) et le Mayo-Kebbi (Sud-Ouest du Tchad). Revue d'Elevage et de Médecine Vétérinaire des Pays Tropicaux 54, 123-127.

Assana, E., Kanobana, K., Tume, C., Zoli, P.A., Nguekam, Geerts, S., Berkvens, D. \& Dorny, P. (2007) Isolation of a $14 \mathrm{KDa}$ antigen from Taenia solium cyst fluid by HPLC and its evaluation in enzyme linked immunosorbent assay for diagnosis of porcine cysticercosis. Research in Veterinary Science 82, 370-376.

Awa, D.N., Njoya, A., Ngo Tama, A.C. \& Ekue, F.N. (1999) The health status of pigs in North Cameroon. Revue d'Elevage et de Médecine Vétérinaire des Pays Tropicaux 52, 93-98.
Berkvens, D., Speybroeck, N., Praet, N., Adel, A. \& Lesaffre, E. (2006) Estimating disease prevalence in a Bayesian framework using probabilistic constraints. Epidemiology 17, 145-153.

Brandt, J., Geerts, S., De Deken, R., Kumar, V., Ceulemans, F., Brijs, L. \& Falla, N. (1992) A monoclonal antibody based ELISA for the detection of circulating excretory-secretory antigens in Taenia saginata cysticercosis. International Journal for Parasitology 22, 471-477.

Carabin, H., Krecek, R.C., Cowan, L.D., Michael, L., Foyaca-Sibat, H., Nash, T. \& Willingham, A.L. (2006) Estimation of the cost of Taenia solium cysticercosis in Eastern Cape Province, South Africa. Tropical Medicine and International Health 11, 906-916.

Dendukuri, N. \& Joseph, L. (2001) Bayesian approaches to modeling the conditional dependence between multiple diagnostic tests. Biometrics 57, 158-167.

Dorny, P., Phiri, I.K., Vercruysse, J., Gabriel, S., Willingham, A.L., Brandt, J., Victor, B., Speybroeck, N. \& Berkvens, D. (2004) A Bayesian approach for estimating values for prevalence and diagnostic test characteristics of porcine cysticercosis. International Journal for Parasitology 34, 569-576.

Flisser, A. \& Gyorkos, T.W. (2007) Contribution of immunodiagnostic tests to epidemiological/intervention studies of cysticercosis/taeniosis. Parasite Immunology 29, 637-649.

Garcia, H.H., Gonzalez, A.E., Gilman, R.H., Palacios, L.G., Jimenez, I., Rodrigues, S., Verastegui, M., Wilkins, P., Tsang, V.C.W. \& the Cysticercosis working group in Peru (2001) Short report: transient antibody response in Taenia solium infection in field conditions - a major contributor to high seroprevalence. American Journal of Tropical Medicine and Hygiene 65, 31-32.

Koussou, M. (1999) Produits nouveaux, négoce et développement local: le cas de la filière porcine au nord du Cameroun. 76 pp. Montpellier, France, CIRAD-EMVT.

Krecek, R.C., Michael, L.M., Schantz, P.M., Ntanjana, L., Smith, M.F., Dorny, P., Harrison, L.J.S., Grimm, F., Praet, N. \& Willingham, A.L. (2008) Prevalence of Taenia solium cysticercosis in swine from a communitybased study in 21 villages of the Eastern Cape Province, South Africa. Veterinary Parasitology 154, 38-47.

Martin, S.W., Meek, A.H. \& Willeberg, P. (1987) Veterinary epidemiology, principles and methods. 343 pp. Ames, Iowa State University Press.

Nana-Nukechap, M.F. \& Gibbs, E.P.J. (1985) Socioeconomic effects of African Swine Fever in Cameroon. Tropical Animal Health and Production 17, 183-184.

Ndebi, G. \& Ongla, J. (2006) Fonctionnement des systèmes de distributions du porc au Cameroun. Tropicultura 24, 73-81.

Njoya, A., Awa, N.D., Moussa, C., Ngo Tama, A.C., Cardinale, E., Ebangi, A.L. \& Ngangué, J.M. (1997) L'élevage porcin au Nord-Cameroun: situation actuelle et possibilités d'amélioration. pp. 516 in Seiny, B.L., Poulain, J.-F. \& Faure, G. (Eds) Agricultures des savanes du Nord-Cameroun. Vers un développement solidaire des savanes d'Afrique Centrale. Montpellier, CIRAD. 
Pawlowski, Z., Allan, J. \& Sarti, E. (2005) Control of Taenia solium taeniasis/cysticercosis: from research towards implementation. International Journal for Parasitology 35, 1221-1232.

Pouedet, M.S.R., Zoli, A., Nguekam, Vondou, L., Assana, E., Speybroeck, N., Berkvens, D., Dorny, P., Brandt, J. \& Geerts, S. (2002) Epidemiological survey of swine cysticercosis in two rural communities of West-Cameroon. Veterinary Parasitology 106, 45-54.

Praet, N., Speybroeck, N., Manzanedo, R., Berkvens, D., Nsame Nforninwe, D., Zoli, A., Quet, F., Preux, P.M. \& Geerts, S. (2009) The disease burden of Taenia solium cysticercosis. PLoS Neglected Tropical Diseases 3, e406.

Prasad, K.N., Prasad, A., Gupta, R.K., Pandey, C.M. \& Singh, U. (2007) Prevalence and associated risk factors of Taenia solium taeniasis in a rural pig farming community of north India. Transactions of the Royal Society of Tropical Medicine and Hygiene 101, 1241-1247.

Shey-Njila, O., Zoli, P.A., Awah-Ndukum, J., Nguekam, Assana, E., Byambas, P., Dorny, P., Brandt, J. \& Geerts, S. (2003) Porcine cysticercosis in village pigs of North-West Cameroon. Journal of Helminthology 77, 351-354.

Sikasunge, C.S., Phiri, I.K., Phiri, A.M., Dorny, P., Siziya, S. \& Willingham, A.L. III (2007) Risk factors associated with porcine cysticercosis in selected districts of Eastern and Southern provinces of Zambia. Veterinary Parasitology 143, 59-66.

Sikasunge, C.S., Phiri, I.K., Phiri, A.M., Siziya, S., Dorny, P. \& Willingham, A.L. III (2008) Prevalence of Taenia solium porcine cysticercosis in the Eastern, Southern and Western Provinces of Zambia. The Veterinary Journal 176, 240-244.

Sokal, R.S. \& Rohlf, J.J. (1981) Biometry: the principles and practice of statistics in biological research. 2nd edn. $859 \mathrm{pp}$. New York, Freeman.

Spiegelhalter, D.J., Thomas, A., Best, N.G. \& Lum, D. (2003) WinBUGS Version 1.4. User Manual Vol. 4, Cambridge, UK, MRC Biostatistics Unit.

Tsang, V.C., Brand, J.A. \& Boyer, A.E. (1989) An enzymelinked immunoelectrotransfer blot assay and glycoprotein for diagnosing human cysticercosis (Taenia solium). The Journal of Infectious Diseases 159, 50-59.

Zoli, A., Geerts, S. \& Vervoort, T. (1987) An important focus of human and porcine cysticercosis in West Cameroon. pp. 85-91 in Geerts, S., Kumar, V. \& Brandt, J. (Eds) Helminth zoonoses. Dordrecht, Martinus Nijhoff Publishers.

Zoli, A.P., Shey-Njila, O., Assana, E., Nguekam, Dorny, P., Brandt, J. \& Geerts, S. (2003) Regional status, epidemiology and impact of Taenia solium cysticercosis in Western and Central Africa. Acta Tropica 87, 35-42. 